\title{
Interaksi Hukum dan Sains dalam Siklus Kebijakan Baku Mutu Udara Ambien
}

\author{
Cecep Aminudin, ${ }^{1,2 *}$ Refial Fadly, ${ }^{1,2}$ Hermawan $^{2}$ \\ ${ }^{1}$ ECOTAS, Cigadung Greenland A9, Bandung 40191 INDONESIA \\ ${ }^{2}$ AFHS Counsellors at Law, Cigadung Greenland A9, Bandung 40191 INDONESIA
}

Kata Kunci:

interaksi, hukum, sains, kebijakan, baku mutu udara ambien

\begin{abstract}
Abstrak
Standar lingkungan seperti Baku Mutu Udara Ambien (BMUA) merupakan inti dari hukum lingkungan khususnya yang menggunakan pendekatan atur dan awasi. Pertimbangan sains sangat penting dalam menentukan BMUA meskipun bukan satu-satunya hal yang dipertimbangkan. Artikel ini bertujuan untuk mengelaborasi lebih lanjut mengenai masalah interaksi hukum dan sains dalam siklus kebijakan BMUA. Ada berbagai peluang interaksi hukum dan sains dalam seluruh siklus kebijakan BMUA yang dapat berkontribusi pada kebijakan dan hukum lingkungan yang lebih baik. Komunikasi sains dan hukum yang efektif merupakan salah satu hal penting bagi interaksi yang lebih bermanfaat.
\end{abstract}

Keywords: interaction, law, science, policy, ambient air quality standards

\section{PENDAHULUAN}

Pada tanggal 16 September 2021, Pengadilan Negeri Jakarta Pusat mengeluarkan putusan atas gugatan warga negara atas nama Melanie Soebono dkk. Vs Negara Republik Indonesia Cq. Presiden Republik Indonesia dkk. yang salah satu amarnya berbunyi "Menghukum Tergugat I [Negara Republik Indonesia Cq. Presiden Republik Indonesiapenulis] untuk - mengetatkan Baku Mutu Udara Ambien Nasional yang cukup untuk melindungi kesehatan manusia, lingkungan, dan ekosistem, termasuk kesehatan populasi yang sensitif berdasarkan pada perkembangan ilmu pengetahuan dan teknologi;" (Pengadilan Negeri Jakarta Pusat 2021).

Putusan Pengadilan Negeri Jakarta Pusat tersebut secara eksplisit menyebutkan keharusan untuk menetapkan Baku Mutu Udara Ambien (BMUA) Nasional berbasis pada perkembangan ilmu pengetahuan dan teknologi (science based).

Sebelum Putusan Pengadilan tersebut dikeluarkan, pada 2 Februari 2021 pemerintah menerbitkan Peraturan Pemerintah Nomor 22

\footnotetext{
*Penulis koresponden: cecep.aminudin@ecotas.org
} 
Tahun 2021 tentang Penyelenggaraan Perlindungan dan Pengelolaan Lingkungan Hidup (PP 22/2021) yang didalamnya mengatur perlindungan dan pengelolaan mutu udara termasuk BMUA Nasional.

BMUA sebagai nilai pencemar udara yang ditenggang keberadaannya dalam udara ambien (Republik Indonesia 2021) merupakan salah satu bentuk Baku Mutu Lingkungan Hidup (BMLH) sebagai ukuran terjadi atau tidaknya pencemaran udara.

BMUA termasuk dalam standar lingkungan. Faure dan Partain membedakan tiga jenis standar lingkungan, yaitu standar target atau kualitas ambien (target or ambient quality standards), standar emisi (emission standards), dan standar produksi atau spesifikasi (production or specification standards) (Faure dan Partain 2019).

Dalam tulisannya, Faure dan Partain menyimpulkan bahwa penetapan standar lingkungan merupakan inti dari hukum lingkungan khususnya yang menggunakan pendekatan atur dan awasi (command and control). Hal ini terkait dengan penetapan tujuan pengelolaan lingkungan, yang didasarkan pada preferensi masyarakat, untuk mencapai tingkat kesejahteraan atau layanan lingkungan yang diinginkan dengan lebih baik. Mereka menyatakan tugas penetapan standar lingkungan adalah hal yang kompleks karena adanya tujuan tertentu yang diinginkan dalam komunitas yang beragam (Faure dan Partain 2019).

Dalam PP 22/2021 disebutkan bahwa BMUA didalamnya berisi jenis parameter dan nilai parameter. Jenis parameter adalah senyawa kimia yang menyebabkan terjadinya pencemaran udara. Misalnya karbon monoksida (CO), hidrokarbon (HC), atau sulfur dioksida $\left(\mathrm{SO}_{2}\right)$. Sedangkan nilai parameter adalah besaran dari konsentrasi zat atau senyawa kimia yang menyebabkan terjadinya pencemaran udara tersebut (Republik Indonesia 2021). Dengan demikian terlihat bahwa konsep-konsep sains khususnya dalam ilmu kimia dan kesehatan lingkungan sangat penting. Oleh karena itu peranan sains dalam pengambilan keputusan mengenai BMUA tidak dapat dihindarkan.

Publikasi WHO menyebutkan, ketika pemerintah harus membuat pilihan kebijakan, mereka membutuhkan saran dan masukan informasi secara teratur dari para ahli. Mereka diharapkan dapat memberikan pendapat yang obyektif sebagai masukan bagi pengambilan keputusan (World Health Organization 1987).

Namun demikian, seperti dikemukakan Faure dan Partain (2019) sebelumnya, penetapan standar lingkungan tidak hanya menyangkut pertimbangan sains namun juga prefensi masyarakat akan tujuan pengelolaan lingkungan.

Uraian sebelumnya tersebut menunjukan eratnya hubungan antara sains dan hukum lingkungan. Namun demikian, dalam penelusuran literatur yang kami lakukan, belum banyak karya tulis berbahasa Indonesia yang mengelaborasi masalah tersebut lebih lanjut khususnya dalam konteks penetapan BMUA. Salah satu karya tulis yang sudah menunjukan hubungan erat antara sains dan hukum lingkungan adalah "Kimia Lingkungan dan Hukum Lingkungan" karya St. Munadjat Danusaputro, Guru Besar Hukum Lingkungan Pertama di Universitas Padjadjaran dan juga di Indonesia, yang diterbitkan tahun 1977. Dalam bukunya tersebut, beliau mengingatkan tentang pentingnya kerjasama antar disiplin ilmu secara interdisiplin bahkan multidisiplin dalam menelaah masalah lingkungan hidup dalam rangka pengelolaannya (Danusaputro 1977).

Dengan pertimbangan tersebut, artikel ini bertujuan untuk mengelaborasi lebih lanjut mengenai masalah interaksi hukum dan sains secara khusus dalam siklus kebijakan BMUA sebagai sebuah studi kasus.

\section{METODE PENELITIAN}

Artikel ini adalah artikel konseptual dengan menggunakan pendekatan adaptasi teori (theory adaptation). Artikel yang fokus pada adaptasi teori, seperti dikemukakan Jaakkola, berusaha untuk mengubah teori yang ada dengan cara menggunakan teori lain. Teori lain tersebut digunakan sebagai alat untuk memberikan kerangka acuan alternatif untuk menyesuaikan atau memperluas ruang lingkup konseptualnya (Jaakkola 2020).

Lebih lanjut Jaakkola menyebutkan jika tinjauan pustaka (literature review) digunakan sebagai alat yang diperlukan tetapi bukan tujuan akhir. Peran tinjauan pustaka adalah untuk mengungkap komponen dari suatu konsep atau fenomena dan kadang-kadang harus mengurangi atau mengecualikan elemen yang tidak dapat dibandingkan (Jaakkola 2020). 


\section{HASIL DAN PEMBAHASAN}

Konsep interaksi sains dan hukum lingkungan yang dipetakan dalam fase yang berbeda dari siklus kebijakan dan peraturan perundang-undangan berangkat dari konsep yang dikemukakan oleh Moore dkk. (2018), sedangkan konsep siklus kebijakan digunakan konsep dari Fischer, Miller, dan Sidney (2007). Konsep mereka dilengkapi dengan konsep Bachmann yang mengemukakan pentingnya penelitian ilmiah terintegrasi dalam setiap tahap siklus pengelolaan kualitas udara (Bachmann 2007). Konsep-konsep mereka kemudian diadaptasi dalam artikel ini.

Peraturan lingkungan sendiri dinamis dan dapat berkembang seiring waktu (Wiryono 2013), seperti yang dikonsepkan oleh siklus kebijakan yang disederhanakan (Gambar 1). Dalam konteks Indonesia, BMUA nasional pertama kali diatur di Indonesia dalam Keputusan Menteri Negara Kependudukan dan Lingkungan Hidup Nomor: Kep02/Menklh/I/1988 tentang Pedoman Penetapan Baku Mutu Lingkungan (KepMenLH 02/1988), kemudian dalam Peraturan Pemerintah Nomor 41 Tahun 1999 tentang Pengendalian Pencemaran Udara (PP 41/1999) dan terakhir dalam Peraturan Pemerintah Nomor 22 Tahun 2021 Tentang Penyelenggaraan Perlindungan dan Pengelolaan Lingkungan Hidup (PP 22/2021). Hal itu menunjukan peraturan lingkungan yang berkembang seiring waktu.

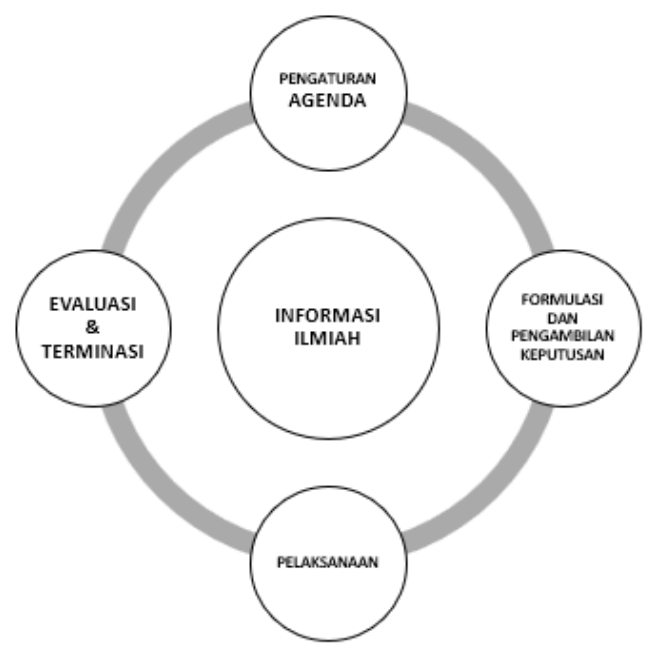

Gambar 1 Peluang interaksi sains dan hukum dalam siklus kebijakan (Modifikasi dari (Moore dkk. 2018; Fischer, Miller, dan Sidney 2007)).
Gambar 1 mengilustrasikan perumusan kebijakan tertentu yang sering kali dirancang untuk menginformasikan pengambilan keputusan, kemudian diimplementasikan. Idealnya, keputusan dan konsekuensinya dievaluasi, dan siklus kembali pada upaya untuk mendesain ulang dan meningkatkan formulasi kebijakan dalam apa yang dapat dikonseptualisasikan sebagai siklus kebijakan yang disederhanakan. Disebut disederhanakan karena mungkin ada proses lain tertentu yang penting dalam siklus tersebut (Moore dkk. 2018; Fischer, Miller, dan Sidney 2007).

Dalam siklus tersebut pemerintah bisa mendapat masukan dari peneliti internal pemerintah sendiri (misalnya di Indonesia peneliti di Pusat Penelitian dan Pengembangan Kualitas dan Laboratorium Lingkungan (P3KLL)) atau mereka yang berada di luar pemerintah seperti akademisi Universitas dan Lembaga Swadaya Masyarakat (LSM).

Dikemukakan Moore dkk. bahwa di seluruh siklus ini, ada berbagai peluang kegiatan berbasis sains yang dapat berkontribusi pada evolusi hukum lingkungan dan pengambilan keputusan yang terkait. Kegiatan tersebut meliputi penelitian serta cara-cara mengomunikasikan ilmu pengetahuan hasil penelitian (Moore dkk. 2018).

Uraian berikutnya menjelaskan potensi interaksi hukum dan sains dalam siklus kebijakan yang disederhanakan itu.

\subsection{Pengaturan Agenda Kebijakan}

Pembuatan hukum dan kebijakan lingkungan dimulai dengan pengakuan adanya permasalahan lingkungan (problem recognition) yang memerlukan solusi kebijakan dan hukum. Hal ini artinya meminta intervensi negara dalam menyelesaikan masalah tersebut.

Setelah pengakuan masalah, langkah berikutnya adalah bahwa masalah yang diakui tersebut benar-benar dimasukan ke dalam agenda pemerintah untuk pertimbangan kebijakan publik secara serius (Fischer, Miller, dan Sidney 2007).

Pengaturan agenda kebijakan BMUA kemungkinan dimulai pada periode tahap perkembangan awal pengaturan kualitas udara di Indonesia sekitar akhir tahun 1970-an dimana dapat dikatakan inisiatif regulasi pengaturan kualitas udara yang lebih bersifat teknis lahir dari daerah provinsi (Aminudin 2016). 
KepGub DKI 587/1980 dapat dikatakan merupakan peraturan pertama yang mengatur BMUA di Indonesia. Penelitian mengenai kualitas udara di kota-kota besar lain di Indonesia pada waktu itu juga menggunakan peraturan ini sebagai acuan (Hardjasoemantri 2009). Pada saat itu, kebijakan lingkungan hidup nasional masih disiapkan oleh kementerian lingkungan hidup yang baru dibentuk pada tahun 1978 (Aminudin 2016).

\subsection{Formulasi Kebijakan dan Pengambilan Keputusan}

Fischer dkk. menguraikan tahap perumusan dan adopsi kebijakan mencakup definisi mengenai tujuan kebijakan, yaitu apa yang harus dicapai dengan kebijakan serta pertimbangan berbagai alternatif tindakan. Apabila pertimbangan berbagai alternatif tindakan merupakan tahap formulasi kebijakan maka adopsi akhir kebijakan adalah pembuatan keputusan formal untuk mengambil kebijakan (Fischer, Miller, dan Sidney 2007).

Dalam penetapan standar lingkungan, ringkasan informasi dan analisis ilmiah yang relevan selain berguna bagi pengambil keputusan juga bermanfaat bagi publik dalam memahami dasar keputusan yang dibuat. WHO menyebutkan, ketika keputusan telah dibuat, adalah bijaksana untuk mencatat alasan di balik pilihan opsi yang dipilih. Ini akan memfasilitasi tinjauan yudisial atau administratif (administrative or judicial review) atas keputusan tersebut, dan akan memungkinkan orang lain untuk memahami dasar keputusan tersebut. Hal ini, lanjutnya, sangat penting ketika tinjauan sedang dilakukan sehubungan dengan data dan informasi baru yang mungkin berdampak atau mungkin tidak berdampak pada keputusan yang diambil (World Health Organization 1987).

Merujuk pada studi Brickman dkk. (1985), yang dilakukan sebagai penyelidikan empiris tentang cara sains digunakan dalam regulasi bahan kimia beracun, WHO menyebutkan bahwa pembentukan peraturan di Amerika Serikat disertai dengan pembenaran analitis yang rumit serta dilengkapi dokumentasi ilmiah. Hal ini berbeda dengan di negara-negara Eropa seperti Inggris, Perancis dan Jerman yang lebih sederhana (World Health Organization 1987).
Pasal 174 ayat (1) PP 22/2021 menyebutkan bahwa BMUA disusun dan ditetapkan dengan mempertimbangkan hasil inventarisasi udara dan aspek kesehatan, sosial, ekonomi, serta lingkungan. Meskipun bagi kami menimbulkan pertanyaan mengenai kepada siapa norma ini dimaksudkan, karena BMUA sendiri sudah ditetapkan dalam lampiran VII PP 22/2021 tersebut, namun hal tersebut memperjelas dasar pertimbangan dalam penetapan BMUA. Norma tersebut mungkin juga dimaksudkan untuk memberikan panduan dalam perubahan BMUA nasional di masa yang akan datang. Untuk mengetahui hasil inventarisasi udara dan aspek kesehatan, sosial, ekonomi, serta lingkungan tentunya membutuhkan penelitian sebelumnya.

WHO menyebutkan bahwa pertimbangan politik dalam pengambilan keputusan lingkungan tidak dapat dihindari. Sehingga kompromi harus diterima meskipun tidak selalu sesuai dengan studi ilmiah yang dilakukan agar program perlindungan lingkungan berhasil dilaksanakan (World Health Organization 1987).

\subsection{Pelaksanaan Kebijakan}

Diungkapkan Fischer dkk. jika keputusan tentang tindakan tertentu dan penerapan suatu program tidak menjamin bahwa tindakan di lapangan akan secara ketat mengikuti maksud dan tujuan pembuat kebijakan. Menurut mereka, tahap pelaksanaan atau penegakan kebijakan oleh lembaga dan organisasi yang berwenang disebut sebagai implementasi kebijakan (policy implementation) (Fischer, Miller, dan Sidney 2007).

Fischer dkk. lebih lanjut menyatakan definisi implementasi kebijakan secara luas mencakup apa yang terjadi antara pembentukan niat nyata dari pihak pemerintah untuk melakukan sesuatu, atau untuk berhenti melakukan sesuatu, dan dampak akhirnya dalam dunia tindakan. Ditambahkannya, tahap ini sangat penting karena tindakan politik dan administratif di dalam kenyataan hampir tidak pernah dapat dikendalikan secara sempurna oleh tujuan, program, peraturan perundangundangan, dan sejenisnya (Fischer, Miller, dan Sidney 2007).

Pada tahap ini saintis dapat berkontribusi dalam memberikan dasar ilmiah (scientific basis) dalam penyusunan pedoman atau standar pelaksanaan, menyampaikan surat terbuka 
(open letters) mengenai kekurangan ilmiah dari pengambilan keputusan, atau menulis opini (op-ed) di media massa mengenai kondisi pelaksanaan kebijakan (Moore dkk. 2018).

Sains juga dapat membantu mengungkapkan kebenaran dalam proses di pengadilan untuk mewujudkan keadilan dalam perkara-perkara lingkungan hidup termasuk yang menyangkut penetapan atau penerapan BMUA. Baik perkara perdata, pidana atau administrasi. Dalam perkara-perkara tersebut, sains dapat membantu proses peradilan dengan menyediakan bukti, fakta, atau pendapat yang dengan itu pengadilan bisa mendapat gambaran mengenai suatu hal berlandaskan metode ilmiah yang memiliki nilai pembuktian. Dalam proses peradilan, kebenaran ilmiah yang dihasilkan oleh proses menurut sains dapat menjadi dasar bagi pembentukan kebenaran menurut hukum (Aminudin 2020).

\subsection{Evaluasi dan Terminasi Kebijakan}

Dalam tahap evaluasi yang menjadi pusat perhatian adalah hasil kebijakan. Apakah tujuan dan dampak kebijakan yang diharapkan tercapai? Evaluasi kebijakan dapat berakhir dengan penghentian kebijakan atau desain ulang kebijakan yang diterapkan (Fischer, Miller, dan Sidney 2007).

Pada tahap evaluasi kebijakan, sains dapat berperan dengan melakukan pemantauan, analisis retrospektif dan masukan ilmiah untuk pembaharuan kebijakan (Moore dkk. 2018). Contoh pemantauan adalah penelitian untuk mengetahui kondisi kualitas udara ambien pada waktu dan tempat tertentu. Analisis retrospektif misalnya dengan meneliti pencapaian target penurunan pencemaran udara di suatu wilayah dalam kurun waktu tertentu. Sedangkan masukan ilmiah misalnya kolaborasi pandangan hukum dan sains dalam pengajuan perubahan BMUA ke pemerintah.

"Kajian baku mutu logam berat di udara ambien sebagai bahan masukan lampiran PP 41/1999 tentang pengendalian pencemaran udara" yang dilakukan Mukhtar dkk., misalnya meneliti baku mutu logam berat di udara ambien dalam PP 41/1999 yang baru terbatas pada logam timbal $(\mathrm{Pb})$. Sedangkan logam berbahaya lainnya seperti arsen (As), kadmium $(\mathrm{Cd})$, merkuri $(\mathrm{Hg})$, kromium $(\mathrm{Cr})$, mangan $(\mathrm{Mn})$, dan nikel $(\mathrm{Ni})$ belum diatur dalam PP tersebut. Selain mengkaji logam berat dalam partikulat udara ambien PM 2.5 sebagai bahan dasar ilmiah dalam rangka revisi lampiran PP
41/1999, penelitian mereka juga melihat nilai baku mutu yang telah diatur dalam PP 41/1999 perlu ditinjau kembali untuk melihat kesesuaiannya dengan kondisi lingkungan atau udara ambien saat ini (Mukhtar dkk. 2014).

\section{PENUTUP}

Ada berbagai peluang interaksi hukum dan sains dalam seluruh siklus kebijakan BMUA yang dapat berkontribusi pada kebijakan dan hukum lingkungan yang lebih baik. Komunikasi sains dan hukum yang efektif merupakan salah satu hal penting bagi interaksi yang lebih bermanfaat.

\section{DAFTAR PUSTAKA}

Aminudin, Cecep. 2016. "Perkembangan Pengaturan Kualitas Udara di Indonesia: dari Pendekatan Tradisional Atur dan Awasi ke arah Bauran Kebajikan." Jurnal Hukum Lingkungan 3 (1): 1-29. https://doi.org/10.38011/jhli.v3i1.39.

2020. "Interaksi Hukum dan Sains dalam Pencarian Kebenaran dalam Proses Peradilan." Jurnal Sosioteknologi 19 (3): 404-11. https://doi.org/10.5614/sostek.itbj.2020 .19.3.8.

Bachmann, John. 2007. "Will the Circle Be Unbroken: A History of the U.S. National Ambient Air Quality Standards." Journal of the Air \& Waste Management Association 57 (6): 652$97 . \quad$ https://doi.org/10.3155/10473289.57.6.652.

Danusaputro, Munadjat. 1977. Kimia Lingkungan dan Hukum Lingkungan. Bandung: Litera.

Faure, Michael G., dan Roy A. Partain. 2019. Environmental Law and Economics Theory and Practice. Cambridge: Cambridge University Press.

Fischer, Frank, Gerald J. Miller, dan Mara S. Sidney. 2007. Handbook of Public Policy Analysis Theory, Politics, and Methods. NW: CRC Press.

Hardjasoemantri, Koesnadi. 2009. Hukum Tata Lingkungan. Edisi VIII, Cetakan Kedua Puluh. Yogyakarta: Gadjah Mada University Press. 
Jaakkola, Elina. 2020. "Designing conceptual articles: four approaches." $A M S$ Review $10 \quad$ (1): 18-26. https://doi.org/10.1007/s13162-02000161-0.

Moore, Jonathan W., Linda Nowlan, Martin Olszynski, Aerin L. Jacob, Brett Favaro, Lynda Collins, G.L. TerriLynn Williams-Davidson, dan Jill Weitz. 2018. "Towards linking environmental law and science." FACETS 3 (1): 375-91. https://doi.org/10.1139/facets-20170106.

Mukhtar, Rita, Susy Lahtiani, Esrom Hamonangan Panjaitan, Hari Wahyudi, Muhayatun Santoso, dan Diah Dwiana Lestiani. 2014. "Kajian baku mutu logam berat di udara ambien sebagai bahan masukan lampiran pp 41/1999 tentang pengendalian pencemaran udara." Ecolab 8 (1): 32-42.

Pengadilan Negeri Jakarta Pusat. 2021. Melanie Soebono dkk. Vs Negara Republik Indonesia Cq. Presiden Republik Indonesia dkk. Pengadilan Negeri Jakarta Pusat.

Republik Indonesia. 2021. Peraturan Pemerintah Nomor 22 Tahun 2021 Tentang Penyelengaraan Perlindungan dan Pengelolaan Lingkungan Hidup.

Wiryono. 2013. Pengantar Ilmu Lingkungan. Edisi Revisi. Bengkulu: Pertelon dan Badan Penerbitan Fakultas Pertanian Universitas Bengkulu.

World Health Organization. 1987. Setting Environmental Srandards. Disunting oleh Koning, Henk W. de (last). Geneva: World Health Organization. https://apps.who.int/iris/handle/10665/ 37172. 